\title{
Палеопротерозойские диориты Троснянского массива Курского блока Сарматии: U-Pb возраст, изотопная систематика и источники расплавов
}

\author{
(C2020 Е. Х. Кориш ${ }^{1}$, К. А. Савко ${ }^{1 凶}$, А. В. Самсонов ${ }^{2}$, М. В. Червяковская ${ }^{3}$ \\ ${ }^{1}$ Воронежский государственный университет, Университетская пл., 1 , \\ 394018, Воронеж, Российская Федерация \\ ${ }^{2}$ Институт геологии рудных месторождений, петрографии, минералогии и геохимии \\ Российской академии наук, Старомонетный пер., 35, 119017, Москва, Российская Федерация \\ ${ }^{3}$ Институт геологии и геохимии им А. Н. Заварицкого, Уральского отделения Российской \\ академии наук, ул. Вонсовского, 15, 620016, Екатеринбург, Российская Федерация
}

\begin{abstract}
Аннотация
Введение: Постколлизионный магматизм Восточной Сарматии с возрастом около 2.06 млрд. лет выражен внедрением в кору огромного объема магм. В пределах архейского Курского блока широко распространены массивы гранитоидов I типа, приуроченные, главным образом, к палеопротерозойской Тим-Ястребовской рифтогенной структуре. Она относится к палеоархейской гранулит-гнейсовой области в восточной части Курского блока. Михайловская палеопротерозойская рифтогенная структура находится в мезоархейской гранит-зеленокаменной области, где доминируют гранитоиды ТТГ ассоциации. Для единственной крупной Троснянской диоритовой интрузии в Михайловской структуре отсутствуют данные по возрасту, элементной и изотопной геохимии, и, соответственно, о ее тектонической позиции и источниках расплавов. Цель настоящей статьи - оценка изотопного возраста, определение источников расплавов и условий кристаллизации для диоритов Троснянской интрузии в Михайловской палеопротерозойской структуре на западе Курского блока.

Методика: Выполнено петролого-геохимическое и геохронологическое изучение диоритов Троснянского массива в Михайловской палеопротерозойской структуре на западе Курского блока.

Результаты и обсуждение: Полученный возраст кристаллизации диоритов Троснянского массива 2058 млн лет отвечает постколлизионному магматическому событию, широко проявленному во всей Сарматии. Распределение редких и редкоземельных элементов в породах и цирконах свидетельствуют о значительных глубинах зарождения расплавов близких к полю устойчивости граната. Кристаллизация диоритового расплава, напротив, имела место на небольших глубинах. Lu-Hf и $\mathrm{Sm}-\mathrm{Nd}$ изотопные данные для диоритов свидетельствуют о длительной коровой предыстории их протолитов, которыми могли быть породы палеоархейского ядра Сарматии.

Заключение: Троснянский диоритовый массив с возрастом 2058 млн лет сформировался во время постколлизионного магматического события (2050-2070 млн лет), имевшего место на всей территории Сарматии. Диоритовые магмы сформировались на значительных глубинах в поле устойчивости граната, в результате контаминации внутриплитных базитов палеоархейским коровым веществом. Кристаллизация диоритового расплава имела место в малоглубинных условиях.

Ключевые слова: Курский блок, диориты, U-Pb изотопный возраст, Lu-Hf систематика, источники расплавов, геохимия цирконов
\end{abstract}

\footnotetext{
$\bowtie$ Савко Константин Аркадьевич, E-mail: ksavko@geol.vsu.ru
} 
Источник финансирования: Работа поддержана Госзаданием ИГЕМ РАН «Петрология и минерагения магматизма внутриплитных и посторогенных обстановок: роль литосферных и астеносферных источников в формировании расплавов», проектами РФФИ № 19-0500159 и РНФ № № 16-17-10283.

Для циттирования: Кориш Е. Х., Савко К. А., Самсонов А. В., Червяковская М. В. Палеопротерозойские диориты Троснянского массива Курского блока Сарматии: U-Pb возраст, изотопная систематика и источники расплавов // Вестник Воронежского государственного университета. Серия: Геология. 2020. №1. С. 87-99. DOI: https://doi.org/10.17308/geology.2020.1/2517

\section{Введение}

Постколлизионный магматизм Восточной Сарматии с возрастом около 2.06 млрд. лет выражен внедрением в кору огромного объема разнообразных магм, совмещенных в пространстве и времени. Это S-, А- и I типы гранитоидов, диоритов, габброидов, сиенитов и карбонатитов [1-5]. Такое многообразие обусловлено различиями в строении литосферы, в составе и длительности предыстории корового субстрата, температур, глубин и степени плавления и коровой контаминацией. В пределах архейского Курского блока наиболее широко распространены массивы гранитоидов I типа стойло-николаевского комплекса, приуроченные, главным образом, к палеопротерозойской Тим-Ястребовской рифтогенной структуре (рис. 1) [2], расположенной в пределах палеоархейской гранулитгнейсовой области в восточной части Курского блока.

Михайловская палеопротерозойская рифтогенная структура находится в мезоархейской гранит-зеленокаменной области, где доминируют гранитоиды ТТГ ассоциации [6]. Для единственной крупной Троснянской диоритовой интрузии в Михайловской структуре отсутствуют данные по возрасту, элементной и изотопной геохимии, и, соответственно, о ее тектонической позиции и источниках расплавов.

Цель настоящей статьи - оценка изотопного возраста, определение источников расплавов и условий кристаллизации для диоритов Троснянской интрузии в Михайловской палеопротерозойской структуре на западе Курского блока.

\section{Геологическая ситуация}

Основной объем архейской коры Курского блока Сарматии представлен двумя типами геологических провинций: архейскими гранулит-гнейсовыми и гранит-зеленокаменными областями (рис. 1). Гранулитгнейсовые и мигматит-гнейсовые области находятся в центральной части площади Курского блока между крупными палеопротерозойскими рифтогенными структурами Тим-Ястребовской и Михайловской (рис. 1). Среди ортогнейсов и мигматитов КурскоБесединской гранулит-гнейсовой области в центральной части Курского Домена отмечаются тела метапелитов, метагабброидов и пород железисто-кремнистой формации, метаморфизованных в условиях гра- нулитовой фации. На западе они граничат с ареалами распространения пород ТТГ ассоциации (рис. 1), среди которых присутствуют небольшие зеленокаменные пояса петельчатой формы, сложенные метавулканитами основного и кислого состава, метакоматиитами, терригенными метаосадочными отложениями, а также породами железисто-кремнистой формации. Они метаморфизованы в условиях не выше амфиболитовой фации [7].

В самом начале палеопротерозоя осадочные отложения курской серии, включающие карбонатные, терригенные породы и ЖКФ, формировались на архейской платформе и имели площадное распространение, но сохранились от размыва только в узких линейных зонах юго-восточно-северо-западного простирания. Эти структуры представляют собой внутриконтинентальные рифты, заложившиеся в середине палеопротерозоя в период 2.3-2.2 млрд. лет назад на архейской платформе. Наиболее крупные из них: Михайловская и Тим-Ястребовская структуры (рис. 1).

В результате коллизии Волгоуралии и Сарматии около 2.1 млрд. лет появился коллизионный ороген [8]. Коллизия сопровождалась складчатостью и метаморфизмом с возрастом 2.07 млрд. лет [9, 10]. Распад коллизионного орогена спровоцировал мощный постколлизионный магматизм в интервале 2.05-2.07 млрд. лет $[1-3,5]$. Среди широкого разнообразия постколлизионных магматических комплексов в Курском блоке самыми распространенными являются диоритгранодиоритовые интрузии стойло-николаевского комплекса с возрастом 2.05-2.07 млрд. лет [2]. Большая часть известных массивов находится в ТимЯстребовской структуре.

В Михайловской структуре находится только один крупный гранитоидный массив - Троснянский, площадью более 75 км² $^{2}$ рис. 1). Он изучен в основном скважинами, пробуренными в 60-х годах прошлого века, керновый материал по которым не сохранился. В нашем распоряжении оказался керн единственной скважины 3577, пробуренной в 1987 г. при глубинном геологическом картировании и вскрывшей в интервале 353.4-484.4 м диориты Троснянского массива.

\section{Петрография и минералогия}

Диориты светло-серой окраски, средне-, крупнозернистые, массивные. Структура гипидиоморфнозернистая, пойкиллитовая. Минеральный состав (мод. $\%$ ): плагиоклаз - 50-65\%, ортопироксен - 5-10\%, роговая обманка $-5-10 \%$, биотит $-5 \%$, кварц (0-10\%) и микроклин (0-10\%). Редко встречаются зерна клинопироксена. Акцессорные минералы: титаномагнетит, апатит, пирит, редкие зерна халькопирита.

Плагиоклаз образует таблитчатые зерна размером до 4 мм в поперечнике с полисинтетическими двойниками (рис. 2), которые характеризуются зональностью по составу: от $\mathrm{An}_{30}$ в центральных частях зерен до $\mathrm{An}_{14}$ в краевых. Плагиоклаз иногда замещается микроклином и кварцем с образованием мирмекитовой и микрографической структуры. 


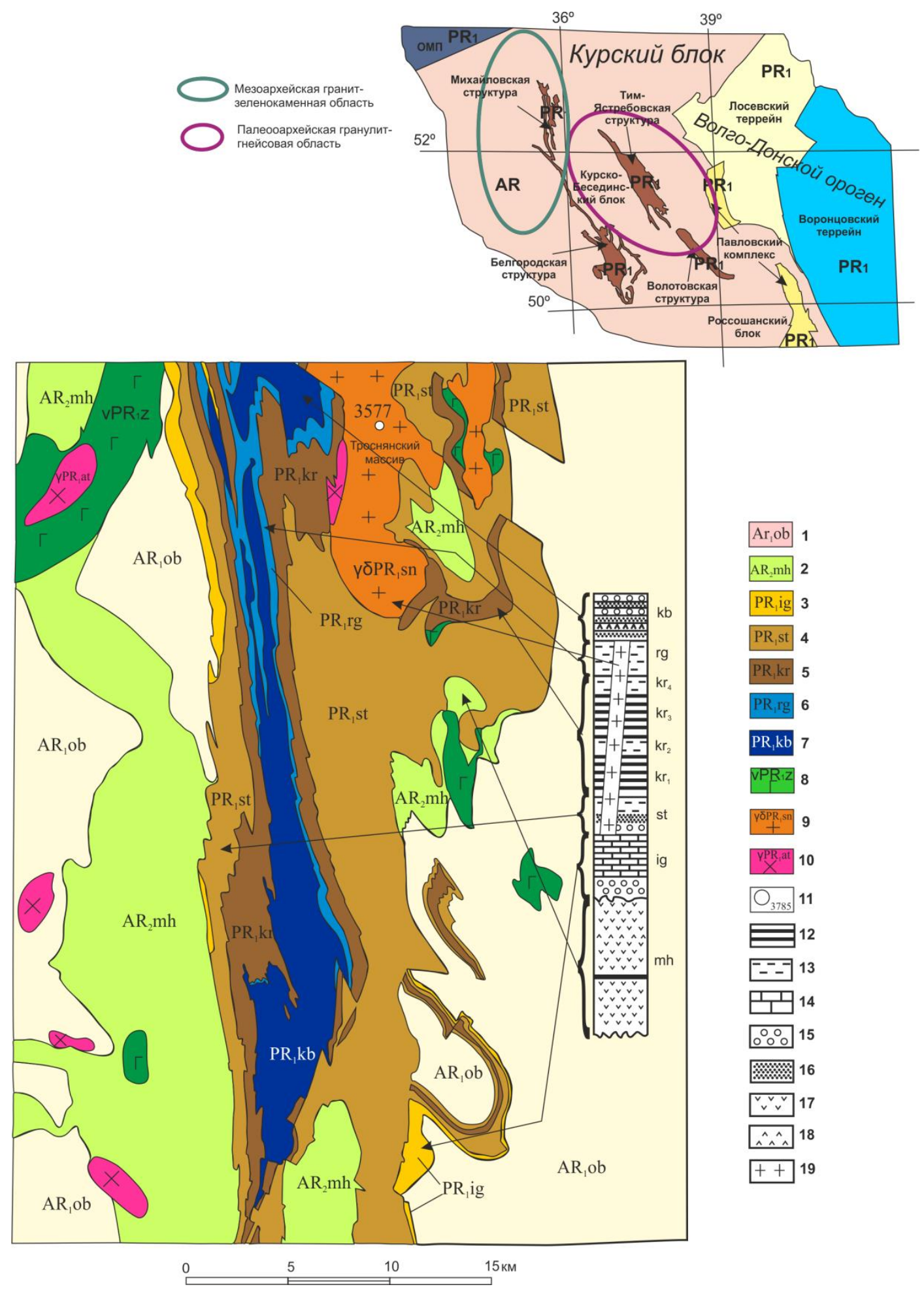

Рис. 1. Схематическая геологическая карта Михайловской структуры и Троснянского массива с врезкой схематической структурной карты Восточной Сарматии: 1 - обоянский комплекс $\left(\mathrm{AR}_{1} \mathrm{ob}\right) ; 2$ - михайловская серия $\left(\mathrm{AR}_{2} \mathrm{mh}\right) ; 3$ - игнатеевская свита $\left(\mathrm{PR}_{1} \mathrm{ig}\right) ; 4$ - стойленская свита $\left(\mathrm{PR}_{1} \mathrm{st}\right) ; 5$ - коробковская свита $\left(\mathrm{PR}_{1} \mathrm{kr}\right) ; 6$ - роговская свита $\left(\mathrm{PR}_{1} \mathrm{rg}\right) ; 7$ - курбакинская свита $\left(\mathrm{PR}_{1} \mathrm{~kb}\right) ; 8$ - золотухинский комплекс $\left(v \mathrm{PR}_{1} \mathrm{z}\right) ; 9$ - стойло-николаевский комплекс $\left(\gamma \delta \mathrm{PR}_{1} \mathrm{sn}\right) ; 10$ - атаманский комплекс $\left(\gamma \mathrm{PR}_{1} \mathrm{at}\right) ; 11$ местоположение и номера скважин; 12 - железистые кварциты; 13 - сланцы; 14 - доломиты; 15 - метаконгломераты; 16 - метапесчаники; 17 - метабазиты; 18 - метариолиты; 19 - гранитоиды.

[Fig. 1. Schematic geological map of the Mikhailovskaya structure and the Trosnyansky Massif with an inset of a sketch map of the Sarmatia general structure: 1 - Oboyan Complex $\left(\mathrm{AR}_{1} \mathrm{ob}\right) ; 2$ - Mikhailovka Group $\left(\mathrm{AR}_{2} \mathrm{mh}\right) ; 3$ - Ignateevo Formation $\left(\mathrm{PR}_{1} \mathrm{ig}\right) ; 4$ - Stoilo Formation $\left(\mathrm{PR}_{1} \mathrm{st}\right) ; 5$ - Korobki Formation $\left(\mathrm{PR}_{1} \mathrm{kr}\right) ; 6$ - Rogovoe Formation $\left(\mathrm{PR}_{1} \mathrm{rg}\right) ; 7$ - Kurbakino Formation $\left(\mathrm{PR}_{1} \mathrm{~kb}\right) ; 8$ - Zolotukhino Complex ( $\left(\mathrm{PR}_{1} \mathrm{z}\right) ; 9$ - Stoilo-Nikolaev Complex $\left(\gamma \delta \mathrm{PR}_{1} \mathrm{sn}\right) ; 10$ - Atamansky Complex $\left(\gamma \mathrm{PR}_{1}\right.$ at); 11 - drillhole numbers; 12 - BIF; 13 shales; 14 - dolomites; 15 - metaconglomerates; 16 - metasandstones; 17 - metabasites; 18 - metarhyolites; 19 - metagranitoides]. 

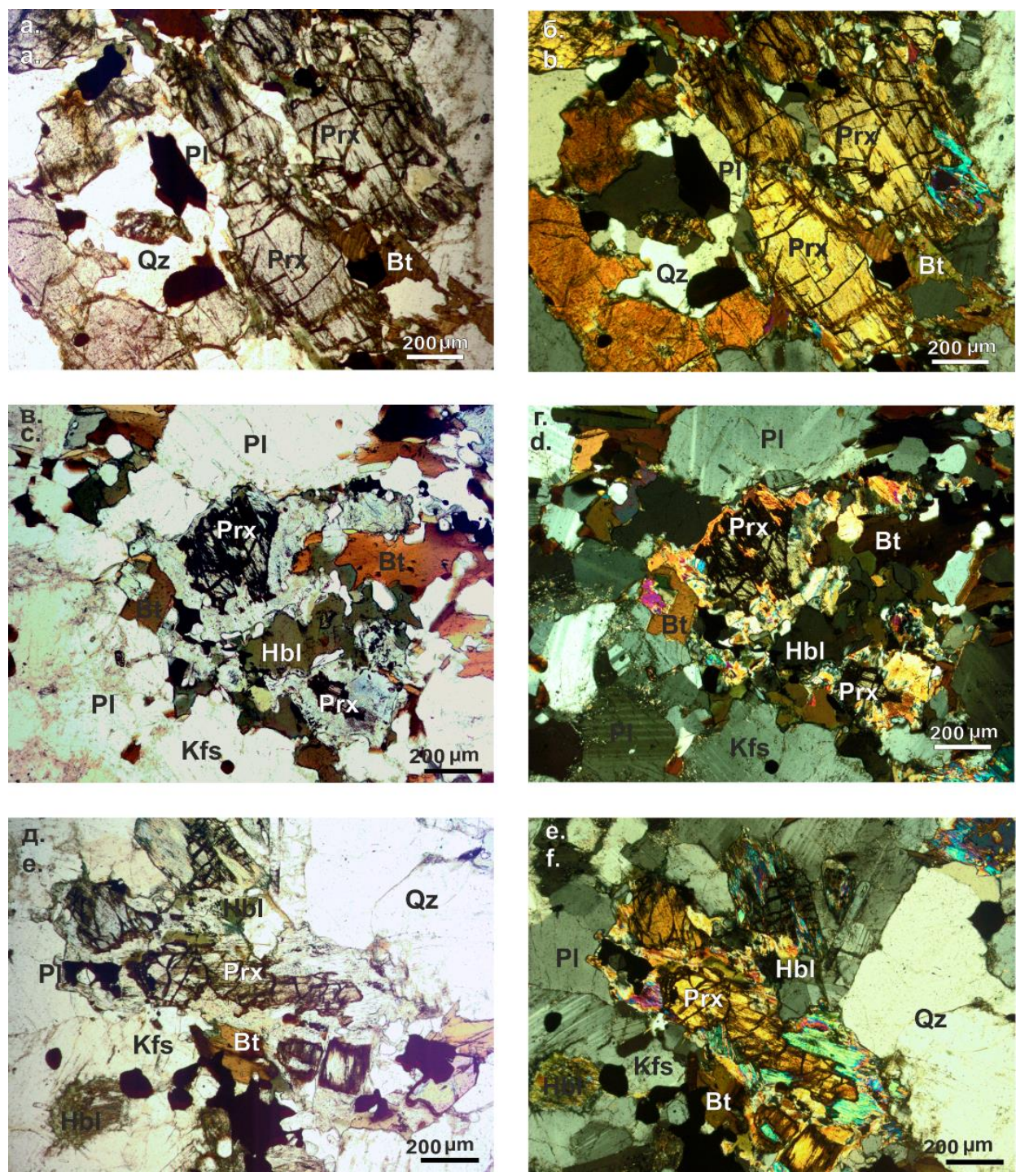

Рис.2. Фото шлифов диоритов Троснянского массива: $a$, 6 - образец 3577/363,4; в, г - образец 3577/409; $\partial$, $e$ - образец $3577 / 480,6$. Аббревиатура минералов по [11].

[Fig. 2 Photomicrographs of the diorites thin sections of the Trosnyansky Massif: $a$, $b$ - sample 3577/363.4; $c, d$ - sample 3577/409; $e, f$ - sample 3577/480.6. Mineral abbreviations after [11]].

Ортопироксен присутствует в виде зерен размером 2-3 мм (рис. 2), часто замещаемых амфиболом и биотитом. Он имеет относительно железистый состав $\left(\mathrm{X}_{\mathrm{Fe}}=0.56-0.64\right)$. Преобладает ортопироксен из группы гиперстена с характерным плеохроизмом в розовых тонах.

Биотит встречается в виде коричневато-бурых чешуек размером до 2 мм (рис. 2) и характеризуется очень высокой титанистостью $\left(\mathrm{TiO}_{2}=4.17-4.89\right.$ мас. $\%)$ и повышенной железистостью $\left(\mathrm{X}_{\mathrm{Fe}}=0.63-0.66\right)$.

Зеленая роговая обманка по имеет повышенную железистость $\left(\mathrm{X}_{\mathrm{Fe}}=0.57-0.60\right)$ и по составу отвечает ферроэдениту.

Аналитические методы исследований

Химический состав проб определен на рентгенофлуоресцентном спектрометре S8 Tiger (Bruker AXS $\mathrm{GmbH}$, Германия) в Воронежском госуниверситете. Подготовка проб для анализа породообразующих элементов выполнена путем плавления 0.5 г порошка пробы, 2 г тетрабората лития в муфельной печи с последующим отливом стеклообразного диска. При калибровке спектрометра и для контроля качества измерений были использованы государственные стандартные образцы химического состава горных пород ГСО №8871-2007, ГСО № 3333-85, ГСО № 3191-85. Точность анализа составляла $1-5 \%$ отн. \% для элементов с концентрациями выше 1-5 мас. \% и до 12 отн. \% для элементов с концентрацией ниже 0.5 мас. \%. Обработка результатов проводилась посредством разработанных методик в программе Spectra Plus (Bruker AXS GmbH, Германия).

Малые и редкие элементы определяли методом индукционно-связанной плазмы с масс-спектрометрическим окончанием анализа (ICP-MS) в АСИЦ ИПТМ РАН. Разложение образцов пород проводилось кислотным вскрытием в открытой и закрытой системах, в зависимости от их состава. Пределы обнаружения для 
REE, Hf, Ta, Th, U составляли 0.02-0.03 ppm, для $\mathrm{Nb}$, $\mathrm{Be}, \mathrm{Co}-0.03-0.05$ ppm, для Li, Ni, Ga, Y - 0.1 ppm, для $\mathrm{Zr}-0.2 \mathrm{ppm}$, для $\mathrm{Rb}, \mathrm{Sr}, \mathrm{Ba}-0.3 \mathrm{ppm}$, для $\mathrm{Cu}, \mathrm{Zn}$, $\mathrm{V}, \mathrm{Cr}-1-2 \mathrm{ppm}$. Правильность анализа контролировалась путем измерения международных и российских стандартных образцов GSP-2, ВM, СГД-1А, СТ1. Ошибки определения концентраций составляли от 3 до 5 мас. \% для большинства элементов.

Выделение циркона проводилось по стандартной методике с использованием тяжелых жидкостей и электромагнитной сепарации. Локальные U-Pb анализы цирконов выполнены в Центре изотопных исследований ВСЕГЕИ (Санкт-Петербург) на ионном микрозонде SHRIMP II по стандартной методике [12] с использованием эталонных цирконов "91500" и "Temora". При расчетах использовали константы распада урана, предложенные в работе [13], поправка на нерадиогенный свинец введена по модели [14] на основе измеренного отношения $204 \mathrm{~Pb} / 206 \mathrm{~Pb}$. Полученные результаты обрабатывали с помощью программ "SQUID v1.12" и "ISOPLOT/Ex 3.22".

Изучение Lu-Hf-изотопного состава цирконов выполнено на многоколлекторном масс-спектрометре Neptune Plus с приставкой для лазерной абляции NWR 213 в Институте геологии и геохимии им. академика А.Н. Заварицкого УрО РАН, г. Екатеринбург. Выполнена оптимизация процедуры обработки экспериментальных данных с использованием стандартов циркона Mud Tank, GJ-1 [15]. Неопределенность единичного измерения отношения ${ }^{176} \mathrm{Hf} /{ }^{177} \mathrm{Hf}$ в виде $2 \mathrm{SD}-$ в интервале 0.005-0.008\%, единичного определения значения $\varepsilon(\mathrm{Hf})$ в виде $2 \mathrm{SD}$ варьировала для перечисленных стандартов в интервале 5-9\%. Параметры процесса лазерной абляции: плотность энергии лазерного излучения - 14 Дж/см², частота повторения импульсов - 20 Гц, диаметр кратера - 25 мкм.

Содержания Ті и других элементов примесей в цирконах определялись методом вторично-ионной масс-спектрометрии в Ярославском Филиале ФизикоТехнологического Института РАН (ЯФ ФТИАН РАН) с использованием вторично-ионного микрозонда CAMECA IMS-4F.

\section{Геохимия}

Диориты характеризуются содержанием $\mathrm{SiO}_{2}$ от 56.4 до 62 мас. \%, обогащены $\mathrm{TiO}_{2}$ (1.5-2.3 мас. \%), являются низкоглиноземистыми (А/CNK от 0.690.96) (рис. 3) и очень высоко железистыми породами $\left(\mathrm{X}_{\mathrm{Fe}}=0.77-0.85\right)$, с относительно постоянным количеством щелочей $\left(\mathrm{K}_{2} \mathrm{O}+\mathrm{Na}_{2} \mathrm{O}=5.3-6.7\right)$, среди которых преобладает $\mathrm{Na}_{2} \mathrm{O}\left(\mathrm{K}_{2} \mathrm{O} / \mathrm{Na}_{2} \mathrm{O}\right.$ от 0.42 до 0.77$)$ (табл. 1). На классификационных диаграммах они попадают в поле кварцевых диоритов и известковощелочных пород (рис. 4).

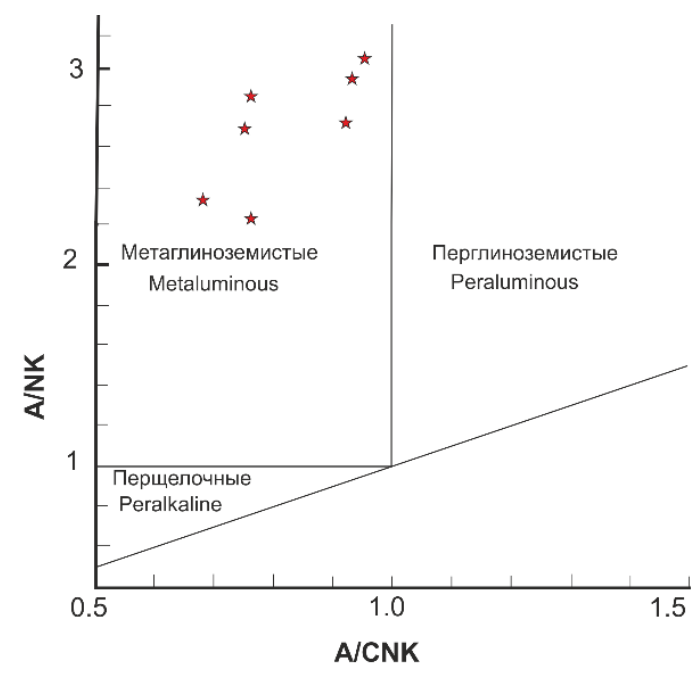

Рис. 3. Составы диоритов Троснянского массива на диаграмме A/NK-A/CNK.

[Fig. 3. $\mathrm{A} / \mathrm{NK}\left(\right.$ molar $\mathrm{Al}_{2} \mathrm{O}_{3} /\left(\mathrm{Na}_{2} \mathrm{O}+\mathrm{K}_{2} \mathrm{O}\right)$ ) versus $\mathrm{A} / \mathrm{CNK}$ (molar $\left.\mathrm{Al}_{2} \mathrm{O}_{3} /\left(\mathrm{CaO}+\mathrm{Na}_{2} \mathrm{O}+\mathrm{K}_{2} \mathrm{O}\right)\right)$ diagram for diorites].

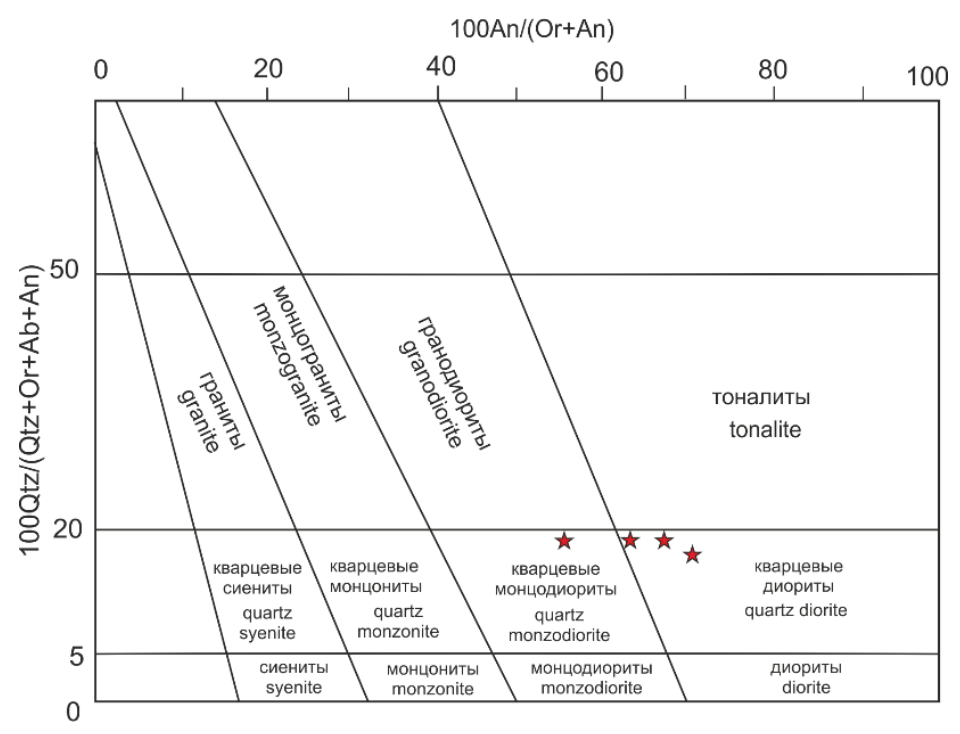

Рис. 4. Составы диоритов Троснянского массива на классификационной диаграмме $100 \mathrm{Qtz} /(\mathrm{Qtz}+\mathrm{Or}+\mathrm{Ab}+\mathrm{An})$ $100 \mathrm{An} /(\mathrm{Or}+\mathrm{An})$

[Fig. 4. Plots of 100Qtz/(Qtz+Or+Ab+An) versus $100 \mathrm{An} /(\mathrm{Or}+\mathrm{An})$ for diorites]. 
Табл. 1. Содержания петрогенных окислов и редких элементов в диоритах Троснянского массива

[Table 1. The contents of petrogenic oxides and rare elements in diorites of the Trosnyansky Massif]

\begin{tabular}{|c|c|c|c|c|c|c|c|}
\hline $\begin{array}{c}\text { Скважина/ } \\
\text { Глубина } \\
\text { [Hole/ } \\
\text { Depth] }\end{array}$ & $\begin{array}{l}3577 / \\
363.4\end{array}$ & $\begin{array}{l}3577 / \\
381.4\end{array}$ & $\begin{array}{c}3577 / \\
405\end{array}$ & $\begin{array}{l}3577 / \\
406.6\end{array}$ & $\begin{array}{c}3577 / \\
409\end{array}$ & $\begin{array}{c}3577 / \\
425\end{array}$ & $\begin{array}{l}3577 / \\
480.6\end{array}$ \\
\hline 1 & 2 & 3 & 4 & 5 & 6 & 7 & 8 \\
\hline $\mathrm{SiO}_{2}$ & 56.23 & 62.01 & 56.44 & 55.99 & 59.89 & 58.11 & 55.78 \\
\hline $\mathrm{TiO}_{2}$ & 2.07 & 2.27 & 1.68 & 1.55 & 2.02 & 1.81 & 1.5 \\
\hline $\mathrm{Al}_{2} \mathrm{O}_{3}$ & 16.33 & 12.89 & 15.03 & 18.28 & 14.73 & 15.35 & 17.2 \\
\hline $\mathrm{Fe}_{2} \mathrm{O}_{3 \text { tot }}$ & 9.59 & 8.72 & 10.20 & 9.04 & 7.54 & 9.85 & 11.1 \\
\hline $\mathrm{MgO}$ & 2.39 & 2.60 & 2.61 & 2.90 & 2.17 & 2.04 & 2.01 \\
\hline $\mathrm{MnO}$ & 0.18 & 0.25 & 0.21 & 0.18 & 0.29 & 0.21 & 0.20 \\
\hline $\mathrm{CaO}$ & 5.14 & 4.47 & 4.60 & 3.89 & 5.92 & 4.84 & 4.0 \\
\hline $\mathrm{Na}_{2} \mathrm{O}$ & 3.42 & 3.26 & 3.59 & 4.80 & 4.58 & 3.53 & 3.6 \\
\hline $\mathrm{K}_{2} \mathrm{O}$ & 1.89 & 2.51 & 1.88 & 1.90 & 1.93 & 1.72 & 2.5 \\
\hline $\mathrm{P}_{2} \mathrm{O}_{5}$ & 0.76 & 0.41 & 0.39 & 0.22 & 0.38 & 0.60 & 0.79 \\
\hline ППП & 1.25 & 0.46 & 1.02 & 1.05 & 0.15 & 1.12 & 0.96 \\
\hline Сумма & 97.00 & 99.84 & 99.05 & 99.80 & 99.59 & 99.18 & 99.64 \\
\hline $\mathrm{X}_{\mathrm{Fe}}$ & 0.80 & 0.77 & 0.79 & 0.82 & 0.78 & 0.83 & 0.85 \\
\hline ASI & 1.20 & 1.35 & 1.10 & 1.78 & 1.25 & 1.15 & 1.95 \\
\hline $\mathrm{K}_{2} \mathrm{O} / \mathrm{Na}_{2} \mathrm{O}$ & 0.55 & 0.77 & 0.52 & 0.40 & 0.42 & 0.49 & 0.69 \\
\hline $\mathrm{K}_{2} \mathrm{O}+\mathrm{Na}_{2} \mathrm{O}$ & 5.31 & 5.77 & 5.47 & 6.70 & 6.51 & 5.25 & 6.1 \\
\hline $\mathrm{A} / \mathrm{CNK}$ & 0.96 & 0.69 & 0.92 & 0.73 & 0.74 & 0.93 & 0.74 \\
\hline $\mathrm{A} / \mathrm{NK}$ & 3.08 & 2.33 & 2.75 & 2.73 & 2.26 & 2.92 & 2.82 \\
\hline $\mathrm{Li}$ & 17.9 & 26.0 & & & 18.5 & & 17.5 \\
\hline $\mathrm{Sc}$ & 27.7 & 11.8 & & & 29.7 & & 22.1 \\
\hline V & 32.3 & 88.9 & & & 31.5 & & 29.5 \\
\hline $\mathrm{Cr}$ & 29.6 & 15.4 & & & 35.6 & & 25.0 \\
\hline Co & 13.9 & 13.3 & & & 13.5 & & 12.1 \\
\hline $\mathrm{Ni}$ & 25.5 & 13.9 & & & 23.7 & & 25.9 \\
\hline $\mathrm{Ga}$ & 20.6 & 19.1 & & & 21.5 & & 18.8 \\
\hline $\mathrm{Rb}$ & 50.6 & 44.7 & & & 64.9 & & 72.2 \\
\hline$S r$ & 849 & 652 & & & 779 & & 624 \\
\hline $\mathrm{Y}$ & 22.3 & 15.6 & & & 25.5 & & 39.0 \\
\hline $\mathrm{Zr}$ & 395 & 114 & & & 171 & & 118 \\
\hline $\mathrm{Nb}$ & 15.8 & 14.9 & & & 14.7 & & 15.0 \\
\hline Mo & 1.4 & 1.7 & & & 1.8 & & 1.4 \\
\hline $\mathrm{Cs}$ & 2.3 & 1.1 & & & 2.8 & & 3.4 \\
\hline Ba & 2205 & 1483 & & & 1816 & & 2055 \\
\hline $\mathrm{La}$ & 32.0 & 26.6 & & & 36.8 & & 57.5 \\
\hline $\mathrm{Ce}$ & 70.4 & 51.5 & & & 76.0 & & 126.6 \\
\hline $\operatorname{Pr}$ & 8.2 & 5.5 & & & 8.8 & & 14.8 \\
\hline $\mathrm{Nd}$ & 34.7 & 22.5 & & & 36.7 & & 58.9 \\
\hline $\mathrm{Sm}$ & 7.1 & 4.3 & & & 7.0 & & 10.9 \\
\hline $\mathrm{Eu}$ & 4.7 & 4.2 & & & 4.3 & & 4.8 \\
\hline $\mathrm{Gd}$ & 6.8 & 3.9 & & & 6.4 & & 9.8 \\
\hline $\mathrm{Tb}$ & 0.91 & 0.55 & & & 0.90 & & 1.3 \\
\hline Dy & 5.1 & 2.8 & & & 4.8 & & 7.0 \\
\hline Ho & 0.99 & 0.54 & & & 0.91 & & 1.30 \\
\hline $\mathrm{Er}$ & 2.8 & 1.6 & & & 2.5 & & 3.6 \\
\hline $\mathrm{Tm}$ & 0.38 & 0.21 & & & 0.32 & & 0.43 \\
\hline $\mathrm{Yb}$ & 2.6 & 1.4 & & & 2.1 & & 2.7 \\
\hline $\mathrm{Lu}$ & 0.40 & 0.21 & & & 0.31 & & 0.38 \\
\hline $\mathrm{Hf}$ & 8.1 & 2.6 & & & 3.9 & & 2.9 \\
\hline $\mathrm{Ta}$ & 1.15 & 0.86 & & & 0.84 & & 0.94 \\
\hline $\mathrm{Tl}$ & - & 0.24 & & & 0.37 & & 0.34 \\
\hline $\mathrm{Pb}$ & 12.6 & 10.3 & & & 9.8 & & 12.5 \\
\hline $\mathrm{Bi}$ & 0.11 & 0.047 & & & 0.076 & & 0.092 \\
\hline $\mathrm{Th}$ & 3.5 & 3.5 & & & 5.9 & & 17.9 \\
\hline
\end{tabular}

Продолжение Табл. 1 [Continued Table 1]

\begin{tabular}{|c|c|c|c|c|c|c|c|}
\hline 1 & 2 & 3 & 4 & 5 & 6 & 7 & 8 \\
\hline $\mathrm{U}$ & 1.4 & 0.92 & & & 1.5 & & 3.7 \\
\hline$\sum \mathrm{REE}$ & 177.1 & 122.1 & & & 164.7 & & 210.7 \\
\hline $\mathrm{Eu} / \mathrm{Eu} *$ & 2.07 & 3.1 & & & 1.9 & & 1.8 \\
\hline $\begin{array}{c}(\mathrm{Gd} / \mathrm{Yb}) \\
\mathrm{n}\end{array}$ & 2.16 & 2.31 & & & 2.52 & & 3.0 \\
\hline$(\mathrm{La} / \mathrm{Yb}) \mathrm{n}$ & 8.83 & 13.63 & & & 12.57 & & 15.27 \\
\hline$(\mathrm{La} / \mathrm{Sm}) \mathrm{n}$ & 2.91 & 0.49 & & & 3.48 & & 0.22 \\
\hline $\mathrm{Rb} / \mathrm{Ba}$ & 0.03 & 0.03 & & & 0.03 & & 0.03 \\
\hline $\mathrm{Ba} / \mathrm{Sr}$ & 2.60 & 2.27 & & & 2.33 & & 2.29 \\
\hline $\mathrm{Sr} / \mathrm{Y}$ & 38 & 25.56 & & & 30.5 & & 16 \\
\hline $\mathrm{La} / \mathrm{Yb}$ & 12.31 & 19 & & & 17.52 & & 21.29 \\
\hline $\mathrm{Yb} / \mathrm{Lu}$ & 6.50 & 6.66 & & & 6.77 & & 7.1 \\
\hline $\mathrm{Nb} / \mathrm{Ta}$ & 13.74 & 26.16 & & & 43.3 & & 62.65 \\
\hline
\end{tabular}

По геохимическим характеристикам диориты выделяются высокими концентрациями $\mathrm{Sr}$ (624-849 ppm) и Ва (1483-2205 ppm) низкими «мафических» элементов $\mathrm{Cr}$ (15.4-35.6 ppm) и $\mathrm{Ni}$ (14-26 ppm) (табл. 1). Высокозарядные элементы характеризуются умеренными $(\mathrm{Zr}=114-395, \mathrm{Y}=15.6-39, \mathrm{Nb}=15-16$, $\mathrm{Th}=3.5-18 \mathrm{ppm})$ содержаниями.

Диориты имеют умеренные концентрации редкоземельных элементов ( $\left.\sum \mathrm{REE}=122-211 \mathrm{ppm}\right)$ (табл. 1) c фракционированным распределением легких и тяжелых $[(\mathrm{La} / \mathrm{Yb}) n=8.8-15.3]$. Отмечаются умеренно фракционированные спектры $\mathrm{HREE}\left(\mathrm{Gd}_{\mathrm{N}} / \mathrm{Yb}_{\mathrm{N}}=2.1-\right.$ 3.0) и резкие положительные $\mathrm{Eu}$ аномалии $\left(\mathrm{Eu} / \mathrm{Eu}^{*}=1.8-3.1\right)$ (табл. 1, рис. 5).

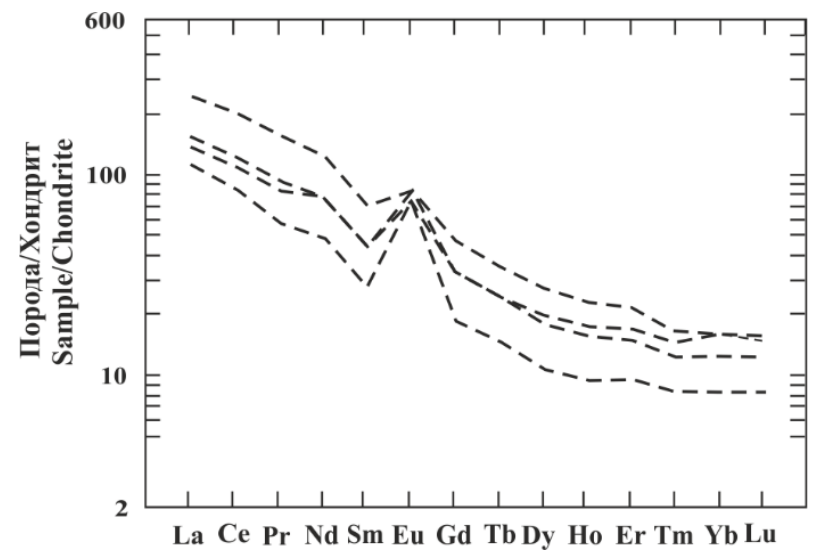

Рис. 5. Распределение редкоземельных элементов в диоритах Троснянского массива.

[Fig. 5. Chondrite-normalized REE patterns of diorites (data are for bulk-rock samples)].

\section{U-Pb геохронология по цирконам}

Нами были выделены цирконы из пробы диоритов (скважина 3577, глубина 363.4) и выполнены определения их возраста на ионном микрозонде SHRIMPII. Циркон представлен прозрачными и полупрозрачными идиоморфными призматическими и изометричными кристаллами размером 150-300 мкм (рис. 6). В режиме катодной люминесценции в циркон темный с осциляционной зональностью и редкими более 


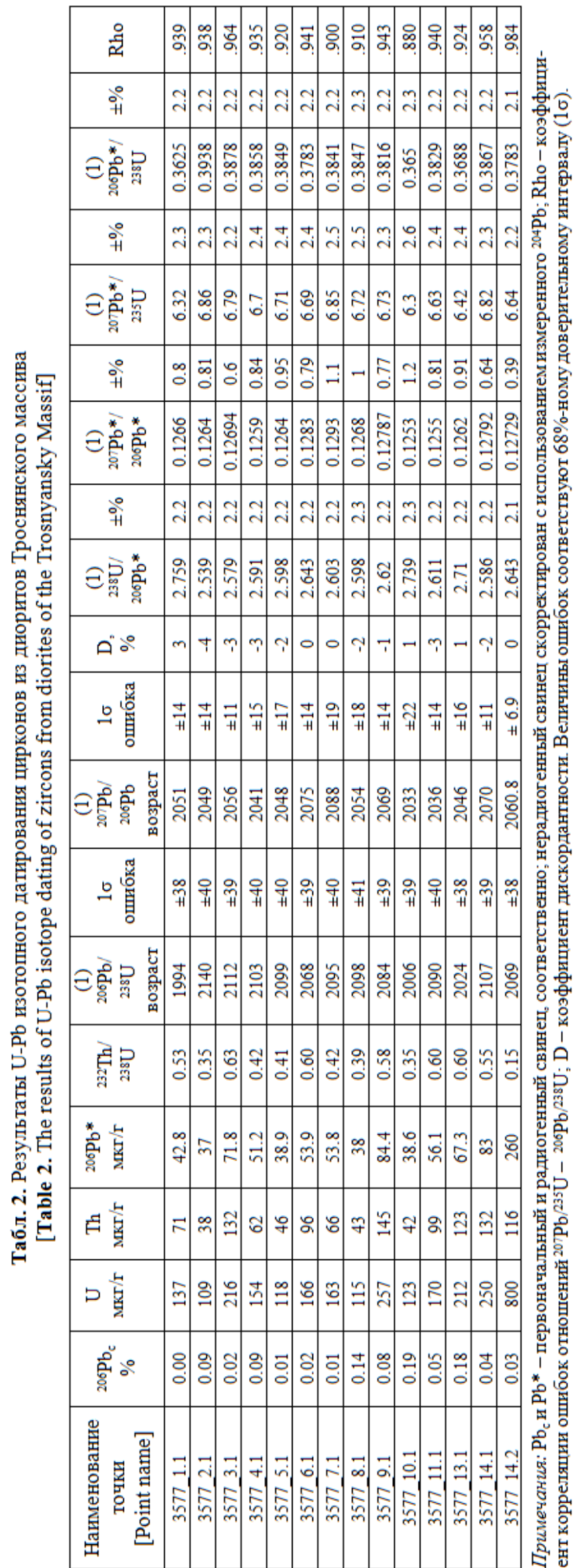
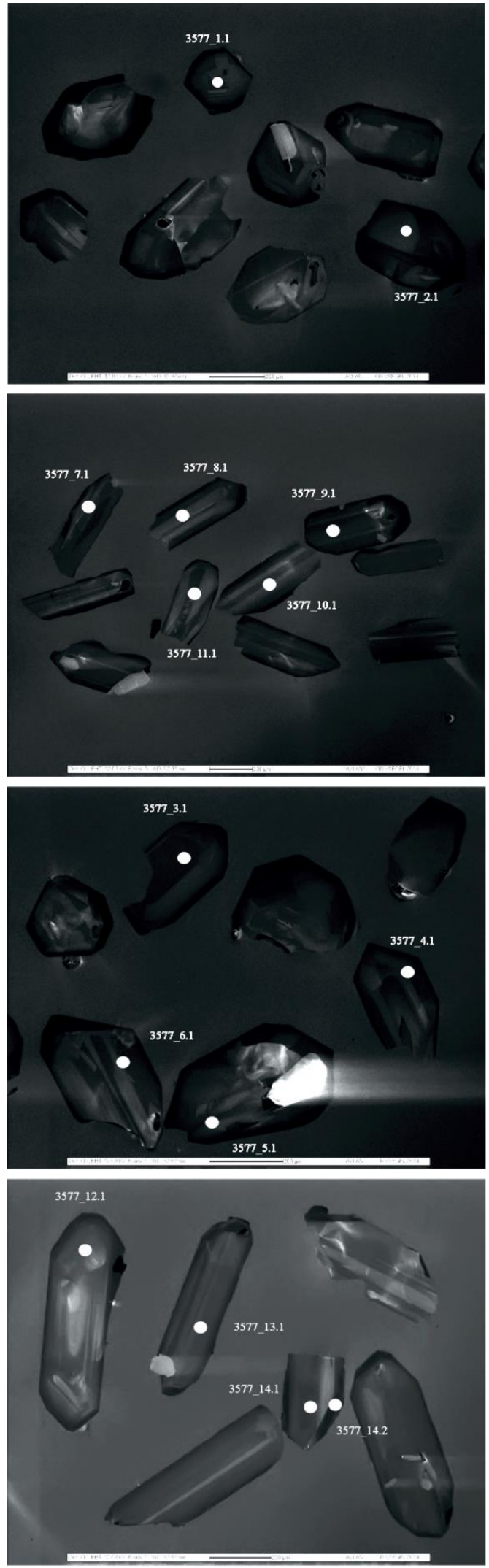

Рис. 6. Расположение точек определения возраста на катодолюминесцентных снимках цирконов из диоритов Троснянского массива.

[Fig. 6. Cathodoluminescence images of zircon grains. Numbers of analytical points correspond to those in the Table 2]. 
светлыми ядрами (рис. 6). В ходе U-Pb геохронологических исследований получены 14 конкордантных и субконкордантных оценок возраста (D < 4\%) циркона (табл. 2), по которым было получена оценка $2060 \pm 8$ млн лет (рис. 7). Среднее значение возраста, рассчитанное по отношению ${ }^{207} \mathrm{~Pb} /{ }^{206} \mathrm{~Pb}$, составляет $2058 \pm 5$ млн лет $($ СКВО $=0.98)$ (рис. 7).

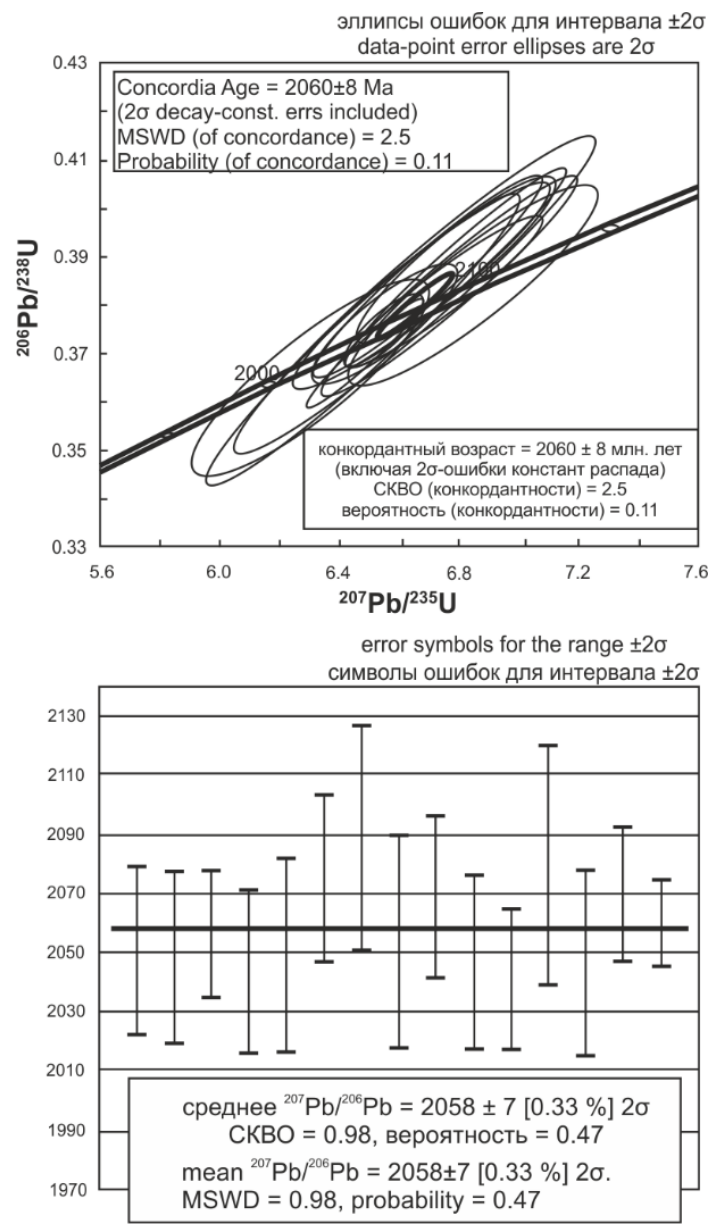

Рис. 7. Результаты U-Pb датирования цирконов из диоритов Троснянского массива методом SIMS. Образец 3577/363,4.

[Fig. 7. The results of U-Pb SIMS analyses of zircons from diorite of the Trosnyansky Massif. Sample $3577 / 363,4$.]

\section{Lu-Hf И Sm-Nd изотопная систематика}

Измерения изотопного состава Нf в цирконах из диоритов Троснянского массива проводились в тех же точках, где определялся $\mathrm{U}-\mathrm{Pb}$ изотопный возраст (табл. 3). В отличие от U$\mathrm{Pb}$ изотопной системы, которая во всех зернах циркона имеет близкий возраст 2.06 млрд. лет, Lu-Hf изотопная система в тех же зернах демонстрирует более широкие вариации изотопного состава гафния на этот возраст $\left(\varepsilon \mathrm{Hf}_{(2058)}\right.$ от -10.1 до -16.1) (табл. 3). Модельные возрасты $\mathrm{T}_{\mathrm{Hf}}(\mathrm{DM})$, рассчитанные по двухстадийной модели, преимущественно палеоархейские варьируют от 3293 до 3663 млн лет.

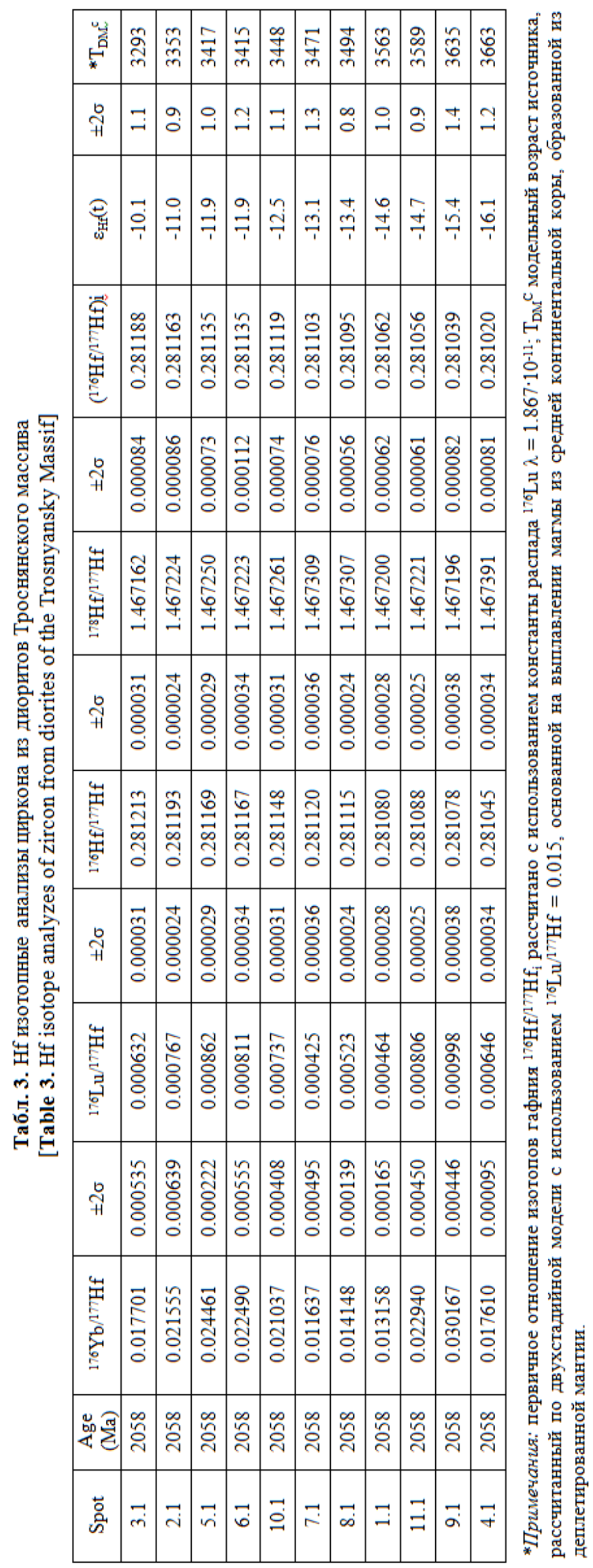


Табл. 4. Sm-Nd изотопные данные диоритов Троснянского массива

[Table 4. Sm-Nd isotopic data of diorites of the Trosnyansky massif]

\begin{tabular}{|c|c|c|c|c|c|c|c|}
\hline $\begin{array}{c}\text { Номер образца } \\
\text { [Sample Number] }\end{array}$ & $\mathrm{Sm}$, мкг/Г & $\mathrm{Nd}$, мкг/Г & ${ }^{147} \mathrm{Sm} /{ }^{144} \mathrm{Nd}^{*}$ & ${ }^{143} \mathrm{Nd} /{ }^{144} \mathrm{Nd}$ & $\mathrm{T}^{* *}$, млн. лет & $\varepsilon_{\mathrm{Nd}}(\mathrm{T})$ & $\mathrm{T}_{\mathrm{Nd}}(\mathrm{DM})^{* * *}$ \\
\hline $3577 / 363.4$ & 5.8 & 30.0 & 0.11740 & 0.511137 & 2050 & -8.4 & 3167 \\
\hline
\end{tabular}

Примечания: * Погрешность ${ }^{147} \mathrm{Sm} /{ }^{144} \mathrm{Nd}$ принята не более $0.2 \%$; ** Возраст по данным U-Pb датирования (см. текст). *** Модельный возраст по [16].

Для образца 3577/363.4 также был измерен изотопный состав $\mathrm{Nd}$ в породе. Величина $\varepsilon \mathrm{Nd}_{(2058)}$ для диорита также имеет отрицательное значение $(-8,1)$. $\mathrm{Sm}-\mathrm{Nd}$ модельный возраст составляет 3167 млн лет (табл. 4).

Таким образом, Lu-Hf и $\mathrm{Sm}-\mathrm{Nd}$ изотопные данные для диоритов свидетельствуют о длительной коровой предыстории их протолитов.

\section{Геохимия цирконов}

Содержания малых элементов в изученных кристаллах циркона отвечают кристаллохимии этого минерала и типичны для магматического циркона из кислых пород [17]. Умеренные концентрации Hf, Th и $\mathrm{U}$ в цирконе (табл. 5) свидетельствуют о его кристаллизации в составе ликвидусной ассоциации на ранней стадии эволюции материнского диоритового расплава. Этот вывод подтверждается температурами кристаллизации циркона, рассчитанными по Ti-in-Zrn термометрам $\left(\mathrm{T}=810-870^{\circ} \mathrm{C}\right)$. Отрицательные $\mathrm{Eu}$ аномалии $\left(\mathrm{Eu} / \mathrm{Eu}^{*}=0.17-0.19\right)$ в цирконе (рис. 8, табл. 5) дают основание говорить, что его кристаллизация происходила одновременно с кристаллизацией плагиоклаза, который является главным концентратом Еu в магмах. Присутствие на ликвидусе плагиоклаза указывает, что диоритовый расплав имел низкие содержания воды и начал кристаллизовался в низкобарических условиях.

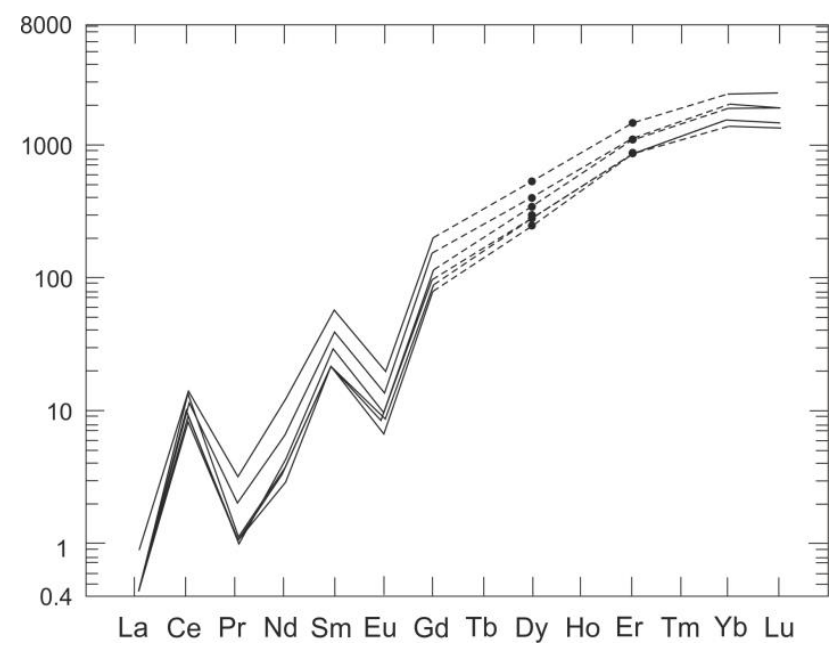

Рис. 8. Нормализованное к хондриту распределение редкоземельных элементов в цирконах из диоритов Троснянского массива.

[Fig. 8. Chondrite-normalized REE patterns for zircons from diorite].
Табл. 5. Содержания редких и редкоземельных элементов в цирконах из диоритов Троснянского массива

[Table 5. The contents of rare and rare earth elements in zircons from diorites of the Trosnyansky Massif]

\begin{tabular}{|c|c|c|c|c|c|c|}
\hline $\begin{array}{c}\text { № точки } \\
\text { [Point } \\
\text { number] }\end{array}$ & $3577-1$ & $3577-2$ & $3577-3$ & $3577-4$ & $3577-5$ & $3577-6$ \\
\hline $\begin{array}{l}\text { Поло- } \\
\text { жение }\end{array}$ & $\begin{array}{l}\text { Центр } \\
\text { [Center] }\end{array}$ & \begin{tabular}{|l} 
Центр \\
[Center]
\end{tabular} & $\begin{array}{l}\text { Центр } \\
\text { [Center] }\end{array}$ & $\begin{array}{l}\text { Центр } \\
\text { [Center] }\end{array}$ & $\begin{array}{l}\text { Центр } \\
\text { [Center] }\end{array}$ & $\begin{array}{l}\text { Центр } \\
\text { [Center }\end{array}$ \\
\hline [|Position] & \begin{tabular}{|l|}
1.1 \\
\end{tabular} & 2.1 & 4.1 & 8.1 & 10.1 & 11.1 \\
\hline $\mathrm{Ti}$ & 22.3 & 14.4 & 15.8 & 13.9 & 14.8 & 13.3 \\
\hline $\mathrm{P}$ & 444 & 312 & 236 & 271 & 432 & 402 \\
\hline Th & 81.2 & 35.0 & 64.4 & 45.3 & 46.4 & 104.1 \\
\hline $\mathrm{U}$ & 204 & 140 & 195 & 149 & 180 & 289 \\
\hline $\mathrm{Hf}$ & 7840 & 8095 & 7906 & 8206 & 8033 & 8138 \\
\hline $\mathrm{Sr}$ & 0.5 & 0.4 & 0.4 & 0.4 & 0.5 & 0.6 \\
\hline $\mathrm{Y}$ & 1194 & 792 & 829 & 810 & 1129 & 1545 \\
\hline $\mathrm{Nb}$ & 41.8 & 22.2 & 22.8 & 15.8 & 13.8 & 13.9 \\
\hline $\mathrm{Ta}$ & 140 & 127 & 128 & 127 & 127 & 133 \\
\hline $\mathrm{Ce}$ & 6.2 & 4.0 & 6.2 & 4.5 & 5.2 & 7.3 \\
\hline $\mathrm{La}$ & 0.1 & 0.1 & 0.2 & 0.1 & 0.1 & 0.1 \\
\hline $\operatorname{Pr}$ & 0.2 & 0.1 & 0.1 & 0.1 & 0.1 & 0.3 \\
\hline $\mathrm{Nd}$ & 3.0 & 1.3 & 1.6 & 1.5 & 2.0 & 5.7 \\
\hline $\mathrm{Sm}$ & 5.9 & 3.0 & 3.0 & 3.2 & 4.4 & 8.5 \\
\hline $\mathrm{Eu}$ & 0.8 & 0.4 & 0.4 & 0.4 & 0.6 & 1.1 \\
\hline $\mathrm{Gd}$ & 30.0 & 15.3 & 16.6 & 18.3 & 23.0 & 39.1 \\
\hline Dy & 103 & 63.1 & 67.7 & 67.7 & 90.1 & 135 \\
\hline Er & 189 & 132 & 132 & 138 & 183 & 243 \\
\hline $\mathrm{Yb}$ & 294 & 224 & 218 & 232 & 306 & 379 \\
\hline $\mathrm{Lu}$ & 47.7 & 37.4 & 36.3 & 38.1 & 49.8 & 62.5 \\
\hline $\mathrm{Th} / \mathrm{U}$ & 0.40 & 0.25 & 0.33 & 0.30 & 0.26 & 0.36 \\
\hline $\mathrm{Hf} / \mathrm{Y}$ & 6.6 & 10.2 & 9.5 & 10.1 & 7.1 & 5.3 \\
\hline $\mathrm{Eu} / \mathrm{Eu}^{*}$ & 0.18 & 0.18 & 0.19 & 0.17 & 0.17 & 0.19 \\
\hline$(\mathrm{Yb} / \mathrm{Gd}) \mathrm{n}$ & 9.8 & 14.6 & 13.1 & 12.7 & 13.3 & 9.7 \\
\hline$(\mathrm{Yb} / \mathrm{Sm})_{\mathrm{n}}$ & 44.8 & 67.3 & 64.7 & 64.6 & 62.9 & 40.0 \\
\hline $\mathrm{T}\left({ }^{\circ} \mathrm{C}\right)^{*}$ & 854 & 808 & 818 & 805 & 812 & 801 \\
\hline $\mathrm{T}\left({ }^{\circ} \mathrm{C}\right) * *$ & 868 & 818 & 829 & 815 & 822 & 810 \\
\hline
\end{tabular}

Примечания: Ti-in-Zrn термометры: *[18]; **[19].

Сильно фракционированные спектры тяжелых РЗЭ в цирконе $\left(\mathrm{Yb}_{\mathrm{N}} / \mathrm{Gd}_{\mathrm{N}}\right.$ от 9.7 до 14.6) (табл. 5, рис. 8) и низкие величины Hf/Y отношений исключают участие граната в кумулусной ассоциации, равновесной с диоритовым расплавом, что дает дополнительные свидетельства о малоглубинных условиях его кристаллизации. Таким образом, данные по элементам - примесям в цирконе дают независимую информацию о диоритовом расплаве, который был относительно сухим и кристаллизовался на небольших глубинах. 


\section{Обсуждение результатов}

Полученный возраст кристаллизации диоритов 2058 млн лет отвечает постколлизионному магматическому событию, широко проявленному во всей Сарматии $[1-3,5]$. Поэтому постколлизионная обстановка формирования Троснянской диоритовой интрузии не вызывает сомнений. Тем не менее, отчетливо проявлена специфика диоритового магматизма, отличающего его от других постколлизионных магматических комплексов Курского блока.

Высокожелезистый состав диоритов $\left(\mathrm{X}_{\mathrm{Fe}}=0.77\right.$ $0.85)$ и сильное фракционирование легких и тяжелых $[(\mathrm{La} / \mathrm{Yb}) \mathrm{n}=8.8-15.3]$ редкоземельных элементов, согласуются c внутриплитной природой мантийных расплавов, контаминированных коровым материалом. Повышенные значения $(\mathrm{Gd} / \mathrm{Yb}) \mathrm{n}$ (до 2.5-3) свидетельствуют о значительных глубинах зарождения расплавов в поле устойчивости граната (фация гранатовых лерцолитов). Отсутствие фракционирования плагиоклаза фиксируется резкими положительными европиевыми аномалиями $\left(\mathrm{Eu} / \mathrm{Eu}^{*}=1.8-3.1\right)$, что подтверждается высокими концентрациями $\mathrm{Sr}$ (624-859 ppm). Кристаллизация диоритового расплава, напротив, имела место на небольших глубинах, как показывает распределение элементов - примесей в цирконе.

Вопрос о возможных контаминантах внутриплитных мантийных расплавов требует специального рассмотрения. Троснянская интрузия диоритов находится в поле развития мезоархейских ТТГ [6] (рис. 1), поэтому было бы логичным предположить, что этими породами и контаминировались внутриплитные базитовые расплавы. Однако такому выводу противоречат изотопные данные, предполагающие для диоритов значительно более древние палеоархейские протолиты. Ими могут быть породы Курско-Бесединской палеоархейской гранулит-гнейсовой области, но они находятся восточнее - между Тим-Ястребовской и Михайловской палеопротерозойскими структурами. Палеоархейская гранулит-гнейсовая область имеет отличную от мезоархейских ТТГ геологическую историю. Палеоархейские гранитогнейсы, метаосадки и габброиды подверглись гранулитовому метаморфизму с возрастом 2.8 млрд. лет [10], который не проявлен в ТТГ [20]. В палеоархейских метаосадках отсутствуют детритовые цирконы с мезоархейскими возрастами, что предполагает пространственную разобщенность гранит-зеленокаменных и гранулитгнейсовых областей до 2.8 млрд. лет. По-видимому, мезоархейские гранит-зеленокаменные области были надвинуты на гранулит-гнейсовые в результате коллизионного события около 2.8 млрд. лет. В этом случае породы гранулит-гнейсовой области, погруженные под гранит-зеленокаменные пояса на значительные глубины в результате коллизии, могут рассматриваться в качестве контаминанта - глубинного источника с длительной коровой предысторией. Такая тектоническая интерпретация объясняет природу смешанного мезоархейского (ТТГ) и палеоархейского (метапелитовые гранулиты) источника расплавов для неоархейских внутриплитных гранитов и риолитов в южном замыкании Тим-Ястребовской структуры [21].

\section{Выводы}

1. Троснянский диоритовый массив с возрастом 2058 млн лет сформировался во время постколлизионного магматического события (2050-2070 млн лет), имевшего место на всей территории Сарматии.

2. По геохимическим признакам диоритовые магмы сформировались на значительных глубинах в поле устойчивости граната, в результате контаминации внутриплитных базитов коровым веществом. Кристаллизация диоритового расплава имела место в малоглубинных условиях.

3. Lu-Hf и Sm-Nd изотопные данные для диоритов свидетельствуют о длительной коровой предыстории их палеоархейских протолитов. Наиболее вероятными контаминантами являются породы КурскоБесединской палеоархейской гранулит-гнейсовой области, глубоко погруженные под Михайловский гранит-зеленокаменный пояс в результате коллизионного события с возрастом около 2.8 млрд. лет.

Благодарности. Работа поддержана Госзаданием ИГЕМ РАН «Петрология и минерагения магматизма внутриплитных и посторогенных обстановок: роль литосферных и астеносферных источников в формировании расплавов», проектами РФФИ № 19-0500159 и РНФ № № 16-17-10283.

Конфликт интересов: Авторы декларируют отсутствие явных и потенциальных конфликтов интересов, связанных с публикацией настоящей статьи

\section{ЛИТЕРАТУРА}

1. Савко К. А., Самсонов А. В., Ларионов А. Н., Ларионова Ю. О., Базиков Н. С. Палеопротерозойские граниты А- и Sтипов востока Воронежского кристаллического массива: геохронология, петрогенезис и тектоническая обстановка формирования // Петрология. 2014а. Т. 22. № 3. С. 235-264. DOI: $10.7868 / \mathrm{S} 0869590314030054$

2. Савко К. А., Самсонов А. В., Базиков Н. С., Козлова Е. Н. Палеопротерозойские гранитоиды Тим-Ястребовской структуры Воронежского кристаллического массива: геохимия, геохронология и источники расплавов// Вестник Воронежского государственного университета. Серия: Геология. 2014б. № 2, С. 56-78. http://www.vestnik.vsu.ru/pdf/heologia/2014/02/2014-02-09.pdf (дата обращения 14.02.2020)

3. Терентьев Р. А., Савко К. А. Высокомагнезиальные низкотитанистые габбро-гранитные серии в палеопротерозое Восточной Сарматии: геохимия и условия формирования // Геология и геофизика. 2016. Т. 57, № 6. С. 1155-1183. DOI: 10.15372/GiG20160605

4. Альбеков А. Ю., Рыборак М. В., Бойко П. С. Реперное $\mathrm{U}-\mathrm{Pb}$ изотопное датирование палеопротерозойских габброидных формаций Курского блока Сарматии (Воронежский кристаллический массив) // Вестник Воронежского государственного университета. Серия: Геология. 2012. № 2. С. 84-94. http://www.vestnik.vsu.ru/pdf/heologia/2012/02/201202-10.pdf (дата обращения 14.02.2020)

5. Terentiev R. A., Savko K. A., Santosh M. Post-collisional two-stage magmatism in the East Sarmatian Orogen, East European Craton: evidence from the Olkhovsky ring complex // J. 
Geol. Soc. 2018. V. 175. P. 86-99. DOI: 10.1144/jgs2017-017 6. Савко К. А., Самсонов А. В., Сальникова Е. Б., Котов А. Б., Ларионов А. Н., Кориш Е. Х., Ковач В. П., Базиков Н. С. Мезоархейские тоналит-трондьемит-гранодиоритовые ассоциации Восточной Сарматии: возраст и геологическое положение // Стратиграфия и геол. коррелящия. 2019. Т. 27. № 5. C. 4-18. DOI: 10.31857/S0869-592X2754-18

7. Савко К. А., Пилюгин С. М., Новикова М. А. Минералогия, фазовые равновесия и условия метаморфизма пород неоархейской железисто-кремнистой формации в пределах Тарасовских аномалий // Вестник Воронежского государственного университета. Серия: Геология. 2004. № 2. С. $111-126$.

http://www.vestnik.vsu.ru/pdf/heologia/2004/02/savko_ka.pdf (дата обращения 14.02.2020)

8. Щипанский А. А., Самсонов А. В., Петрова А. Ю., Ларионова Ю. О. Геодинамика восточной окраины Сарматии в палеопротерозое // Геотектоника. 2007. № 1. С. 43-70. https://elibrary_9462648_67590005 (дата обращения 14.02. 2020)

9. Савко К. А., Самсонов А. В., Сальникова Е. Б., Котов А. Б., Базиков Н. C. HT/LP Метаморфическая зональность восточной части Воронежского кристаллического массива: возраст, условия и геодинамическая обстановка формирования // Петрология. 2015. Т. 23. №6. С. 607-623. DOI: 10.7868/S0869590315050040

10. Savko K. A., Samsonov A. V., Kotov A. B., Sal'nikova E. B., Korish E. H., Larionov A. N., Anisimova I. V., Bazikov N. S. The Early Precambrian Metamorphic Events in Eastern Sarmatia // Precambrian Research. 2018. V. 311. pp.1-23. DOI: 10.1016/j.precamres. 2018.04.009

11. Whitney D. L., Evans B. W. Abbreviations for names of rock-forming minerals // Am. Mineral. 2010. V. 95. pp. 185187. DOI: $10.2138 / \mathrm{am} .2010 .3371$

12. Larionov A. N., Andreichev V. A., Gee D. G. The Vendian alkaline igneous suite of northern Timan: ion microprobe $\mathrm{U}-\mathrm{Pb}$ zircon ages of gabbros and syenite // The Neoproterozoic Timanide Orogen of Eastern Baltica. Eds. Gee D.G., Pease V.L. Geol. Soc. London Mem. 2004. V. 30. pp. 69-74. DOI: 10.1144/GSL.MEM.2004.030.01.07
13. Steiger R. H., Jager E. Subcomission of geochronology: convention of the use of decay constants in geo- and cosmochronology // Earth Planet. Sci. Lett. 1976. V. 36. No. 2. pp. 359 -362. DOI: 10.1016/0012-821X(77)90060-7

14. Stacey J. S., Kramers I. D. Approximation of terrestrial lead isotope evolution by a two-stage model // Earth Planet. Sci. Lett. 1975. V. 26. No. 2. pp. 207-221. DOI: 10.1016/0012821X(75)90088-6

15. Jackson S. E., Norman J. P., William L. G., Belousova E. A. The application of laser ablation-inductively coupled plasmamass spectrometry to in situ U-Pb zircon geochronology // Chem. Geol. 2004. V. 211. pp. 47-69. DOI:10.1016/j.chemgeo.2004.06.017

16. Goldstein S. J., Jacobsen S. B. Nd and Sr Isotopic systematics of river water suspended material - implications for crustal evolution // Earth Planet. Sci. Lett. 1988. V. 87. No. 3. pp. 249 266. DOI: $10.1016 / 0012-821 X(88) 90013-1$

17. Hoskin P. W. O., Schaltegger U., The composition of zircon and igneous and metamorphic petrogenesis // Rev. Mineral. Geochem. 2003. V. 53. pp. 27-62. DOI: 10.2113/0530027

18. Watson E. B., Wark D. A., Thomas J. B. Crystallization thermometers for zircon and rutile // Contrib. Mineral. Petrol. 2006. V. 151. pp. 413-433. DOI 10.1007/s00410-006-0068-5

19. Ferry J. M., Watson E. B. New thermodynamic models and revised calibrations for the Ti-in-zircon and $\mathrm{Zr}$-in-rutile thermometers // Contrib. Mineral. Petrol. 2007. V.154. pp. 429437. DOI 10.1007/s00410-007-0201-0

20. Савко К. А., Самсонов А. В., Ларионов А. Н., Кориш Е. Х., Червяковская М. В., Базиков Н. С. Эпизоды роста континентальной коры в раннем докембрии Сарматии // в кн. «Фундаментальные вопросы тектоники и геодинамики». Т. 2. Мат. LII Тектонического совещания. М.: «ГЕОС». 2020. C. 270-273. http://www.ginras.ru/materials/files/MTS-20202\%20.pdf (дата обращения 14.02.2020)

21. Savko K. A., Samsonov A. V., Kholina N. V., Larionov A. N., Zaitseva M. V., Korish E. H., Bazikov N. S., Terentiev R. A. $2.6 \mathrm{Ga}$ high-Si rhyolites and granites in the Kursk Domain, Eastern Sarmatia: Petrology and application for the Archaean palaeocontinental correlations// Precambrian Research. 2019. V. 322. pp. 170-192. DOI: 10.1016/j.precamres.2019.01.006
Кориш Екатерина Хафисовна - ведущий инженер лаборатории комплексных исследований, Воронежский государственный университет, Воронеж, Российская Федерация; E-mail: korish_k@rambler.ru; ORCID https://orcid.org/0000-0002-6573-1272

Савко Константин Аркадьевич - д.г.-м.н., профессор, заведующий кафедрой полезных ископаемых и недропользования, Воронежский государственный университет, Воронеж, Российская Федерация; E-mail: ksavko@geol.vsu.ru; ORCID https://orcid.org/0000-0002-7291-7024

Самсонов Александр Владимирович - д.г.-м.н., членкорреспондент РАН, главный научный сотрудник, Институт геологии рудных месторождений, петрографии, минералогии и геохимии РАН, Москва, Российская Федерация;

E-mail: samsonov@igem.ru;

ORCID https://orcid.org/0000-0003-4101-6159

Червяковская Мария Владимировна - аспирант, Институт геологии и геохимии им. академика А. Н. Заварицкого Уральского отделения РАН, Екатеринбург, Российская Федерация; E-mail: masha_vuf_91@ mail.ru;

Авторы прочитали и одобрили окончательный вариант рукописи.
Ekaterina Kh. Korish - leading engineer, Integrated Research Laboratory, Voronezh State University, Voronezh,

Russian Federation;

E-mail: korish_k@rambler.ru; ORCID https://orcid.org/0000-0002-6573-1272

Konstantin. A. Savko - PhD, Dr. habil. in Geol.-Min., Professor, Head of the Department of Mineral Resources and Mineral Management Studies, Voronezh State University, Voronezh, Russian Federation; E-mail: ksavko@geol.vsu.ru; ORCID https://orcid.org/0000-0002-7291-7024

Alexandr V. Samsonov - PhD, Dr. habil. in Geology and Mineralogy, Associate Member of the RAS, chief researcher, Institute of Geology of Ore Deposits, Petrography, Mineralogy and Geochemistry RAS, Moscow, Russian Federation;

E-mail: samsonov@igem.ru;

ORCID https://orcid.org/0000-0003-4101-6159

Maria V. Chervyakovskaya - postgraduate student, Zavaritsky Institute of Geology and Geochemistry of the Ural Branch of the Russian Academy of Sciences, Yekaterinburg, Russian

Federation; E-mail: masha_vuf_91@ @ail.ru;

All authors have read and approved the final manuscript. 


\title{
Paleoprotherozoic diorites of the Trosnyansky Massif within the Kursk Block of Sarmatia: U-Pb age, isotope systematics and sources of melts
}

\author{
(C) 2020 E. Kh. Korish ${ }^{1}$, K. A. Savko ${ }^{1 凶}$, A. V. Samsonov ${ }^{2}$, M. V. Chervyakovskaya ${ }^{3}$ \\ ${ }^{1}$ Voronezh State University, 1 Universitetskaya pl., Voronezh, 394018, Russian Federation \\ ${ }^{2}$ Institute of Ore Deposits, Petrography, Mineralogy and Geochemistry of the Russian Academy of Scienc- \\ es, 35 Staromonetny per, Moscow, 119017, Russian Federation \\ ${ }^{3}$ Zavaritsky Institute of Geology and Geochemistry of the Ural Branch of the Russian Academy of Scienc- \\ es, 15 Akademika Vonsovskogo st., Yekaterinburg, 620016, Russian Federation
}

\begin{abstract}
Introduction: The post-collisional magmatism in East Sarmatia with an age of about 2.06 billion years is expressed by the introduction of a huge amount of magma into the crust. Within the Archean Kursk Block, granitoid massifs of type I, confined mainly to the Paleoproterozoic Tim-Yastrebovskaya rift structure are widespread. Tim-Yastrebovskaya rift structure is confined to the granulite-gneiss Paleoarchean region in the eastern part of the Kursk Block. The Paleoproterozoic Mikhailovskaya riftogenic structure is located in the Mesoarchaean granite-greenstone region, where the TTG granitoids are dominant. Only for the large diorite intrusion of Trosnyansky Massif in the Mikhailovskaya structure, there are no data on age, elemental and isotopic geochemistry, and, accordingly, its tectonic position and sources of melts. The purpose of this study was estimation of the isotopic age, the determination of the sources of melts and crystallization conditions for diorite intrusion of Trosnyansky Massif in the Paleoproterozoic Mikhailovskaya structure in the west of Kursk Block.

Methodology: A petrological-geochemical and geochronological study was carried out on the diorites of the Trosnyansky Massif in the Paleoproterozoic Mikhailovskaya structure in the west of Kursk Block.

Results and discussion: The obtained crystallization age of diorites of the Trosnyansky Massif of 2058 Ma corresponds to a post-collision magmatic event, widely manifested throughout Sarmatia. The distribution of rare and rare-earth elements in rocks and zircons indicates significant depths of nucleation of melts close to the stability field of garnet. Crystallization of diorite melt, in contrast, occurred at shallow depths. The Lu-Hf and Sm-Nd isotopic data for diorites indicate a long crustal history of their protoliths, which could be the rocks of the Paleoarchean core of Sarmatia.

Conclusions: The Trosnyansky Diorite Massif with an age of $2058 \mathrm{Ma}$ was formed during the postcollisional magmatic event (2050-2070 Ma) that took place throughout Sarmatia. Diorite magmas were formed at considerable depths in the stability field of garnet, as a result of the contamination of intraplate basites by Paleoarchean crust. Crystallization of diorite melt occurred under shallow conditions.

Keywords: Kursk Block, diorite, U-Pb isotopic age, Lu-Hf systematics, sources of melts, geochemistry of zircon.

Funding: This study was financially supported by the State task of Institute of Ore Deposits, Petrography, Mineralogy and Geochemistry of the Russian Academy of Sciences "Petrology and mineralization of magmatism of intraplate and postorogenic environments: the role of lithospheric and asthenospheric sources in the formation of melts", projects of the Russian Foundation for Basic Research no. 19-0500159 and Russian Science Foundation no. 16-17-10283.
\end{abstract}

\footnotetext{
${ }^{凶}$ Konstantin A. Savko, e-mail: ksavko@geol.vsu.ru
} 
For citation: Korish E. H., Savko K. A., Samsonov A.V., Chervyakovskaya M. B. Paleoprotherozoic diorites of the Trosnyansky Massif within Kursk Block of Sarmatia: U$\mathrm{Pb}$ age, isotope systematics and sources of melts. Vestnik Voronezhskogo gosudarstvennogo universiteta. Seriya: Geologiya $=$ Proceedings of Voronezh State University. Series: Geology, 2020, no. 1, pp. 87-99. DOI: https://doi.org/10.17308/geology.2020.1/2517

Conflict of interest: The authors declare the absence of obvious and potential conflicts of interest related to the publication of this article.

\section{REFERENCES}

1. Savko K. A., Samsonov A. V., Larionov A. N., Larionova Yu. O., Bazikov N. S. Palaeoproterozoic A and S-granites in the eastern Voronezh crystalline massif: geochronology, petrogenesis, and tectonic setting of origin. Petrology, 2014a, vol. 22, no. 3. pp. 205-233. DOI: 10.1134/S0869591114030059

2. Savko K.A., Samsonov A.V., Bazikov N. S., Kozlova E. N. Palaeoproterozoic granitoids of the Tim-Yastrebovskaya structure of the Voronezh Crystalline Massif: geochemistry, geochronology and melt sources. Vestnik Voronezhskogo gosudarstvennogo universiteta. Seriya: Geologiya $=$ Proceedings of Voronezh State University. Series: Geology, 2014b, no. 2, pp. 56-78. http://www.vestnik.vsu.ru/pdf/heologia/2014/02/201402-09.pdf (accessed 14.02.2020). (in Russ.)

3. Terentiev R. A., Savko K. A. Paleoproterozoic high-Mg low-Ti gabbro-granite series in eastern Sarmatia: geochemistry and formation conditions. Russian Geology and Geophysics, 2016, vol. 57, pp. 907-932. DOI: 10.1016/j.rgg.2015.06.012

4. Al'bekov A. Yu., Ryborak M. V., Boiko P. S. Reference U$\mathrm{Pb}$ isotope dating of Paleoproterozoic gabbroid formations of the Kursk block of the Sarmatia (Voronezh Crystalline Massif). Vestnik Voronezhskogo gosudarstvennogo universiteta. Seriya: Geologiya $=$ Proceedings of Voronezh State University. Series: Geology, 2012, no. 2, pp. 84-94. http://www.vestnik.vsu.ru/pdf/ heologia/2012/02/2012-02-10.pdf (accessed 14.02.2020) (in Russ.)

5. Terentiev R. A., Savko K. A., Santosh M. Post-collisional two-stage magmatism in the East Sarmatian Orogen, East European Craton: evidence from the Olkhovsky ring complex. J. Geol. Soc, 2018, vol. 175, pp. 86-99. DOI: 10.1144/jgs2017-017

6. Savko K. A., Samsonov A. V., Sal'nikova E. B., Kotov A. B., Larionov A. N., Korish E. H., Kovach V. P., Bazikov N. S. The Mesoarchean Tonalite-Trondhjemite-Granodiorite Associations of Eastern Sarmatia: Age and Geological Setting. Stratigraphy and Geological Correlation, 2019, vol. 27, no. 5, pp. 499-513. DOI: 10.1134/S086959381905006X

7. Savko K. A., Pilugin S. M., Novikova M. A. Mineralogy, phase equilibriums, and metamorphic conditions of Neoarchaean banded iron formations within the Tarasov anomaly. Vestnik Voronezhskogo gosudarstvennogo universiteta. Seriya: Geologiya = Proceedings of Voronezh State University. Series: Geology, 2004, no. 2, pp. 111-126. http://www.vestnik.vsu.ru/pdf/heologia/2004/02/savko_ka.pdf (accessed 14.02.2020). (in Russ.)

8. Shchipanskii A. A., Samsonov A. V., Petrova A. Yu., Larionova Yu. O., Geodynamics of the Eastern Margin of Sarmatia in the Paleoproterozoic. Geotectonics, 2007, vol. 41, no. 1, pp. 38-62. https://elibrary_9462648_67590005 (accessed 14.02.
2020) (in Russ.)

9. Savko K. A., Samsonov A. V., Sal'nikova E. B., Kotov A. B., Bazikov N. S., HT/LP metamorphic zoning in the eastern Voronezh Crystalline Massif: age and parameters of metamorphism and its geodynamic environment. Petrology, 2015, vol. 23, no. 6, pp. 559-575. DOI: 10.1134/S0869591115050045

10. Savko K. A., Samsonov A. V., Kotov A. B., Sal'nikova E. B., Korish E. H., Larionov A. N., Anisimova I. V., Bazikov N. S. The Early Precambrian Metamorphic Events in Eastern Sarmatia. Precambrian Research, 2018, vol. 311, pp.1-23. DOI: 10.1016/j.precamres.2018.04.009

11. Whitney D. L., Evans B. W. Abbreviations for names of rock-forming minerals. Am. Mineral., 2010, vol. 95. pp. 185187. DOI: $10.2138 / \mathrm{am} .2010 .3371$

12. Larionov A. N., Andreichev V. A., Gee D. G. The Vendian alkaline igneous suite of northern Timan: ion microprobe $\mathrm{U}-\mathrm{Pb}$ zircon ages of gabbros and syenite. The Neoproterozoic Timanide Orogen of Eastern Baltica. Eds. Gee D. G., Pease V. L. Geol. Soc. London Mem., 2004, vol. 30, pp. 69-74. DOI: 10.1144/GSL.MEM.2004.030.01.07

13. Steiger R. H., Jager E. Subcomission of geochronology: convention of the use of decay constants in geo- and cosmochronology. Earth Planet. Sci. Lett., 1976, vol. 36, no. 2, pp. 359-362. DOI: 10.1016/0012-821X(77)90060-7

14. Stacey J. S., Kramers I. D. Approximation of terrestrial lead isotope evolution by a two-stage model. Earth Planet. Sci. Lett., 1975 , v. 26, no. 2, pp. 207-221. DOI: 10.1016/0012821X(75)90088-6

15. Jackson S. E., Norman J. P., William L. G., Belousova E. A. The application of laser ablation-inductively coupled plasmamass spectrometry to in situ U-Pb zircon geochronology. Chem. Geol., 2004, vol. 211, p. 47-69. DOI:10.1016/j.chemgeo.2004.06.017

16. Goldstein S. J., Jacobsen S. B. Nd and Sr Isotopic systematics of river water suspended material - implications for crustal evolution. Earth Planet. Sci. Lett., 1988, vol. 87, no. 3, pp. 249266. DOI: $10.1016 / 0012-821 X(88) 90013-1$

17. Hoskin P. W. O., Schaltegger U. The composition of zircon and igneous and metamorphic petrogenesis. Rev. Mineral. Geochem., 2003, vol. 53, pp. 27-62. DOI: 10.2113/0530027

18. Watson E. B., Wark D. A., Thomas J. B. Crystallization thermometers for zircon and rutile. Contrib. Mineral. Petrol, 2006, vol. 151, pp. 413-433. DOI 10.1007/s00410-006-0068-5

19. Ferry J. M., Watson E. B. New thermodynamic models and revised calibrations for the Ti-in-zircon and $\mathrm{Zr}$-in-rutile thermometers. Contrib. Mineral. Petrol, 2007, vol. 154, pp. 429437. DOI 10.1007/s00410-007-0201-0

20. Savko K. A., Samsonov A. V., Larionov A. N., Korish E. H., Chervyakovskaya M. V., Bazikov N. S. Episodes of the continental crust growth in the early Precambrian of Sarmatia. In «Fundamental'nye voprosy tektoniki I geodinamiki» [Fundamental issues of tectonics and geodynamics] Moscow, Publ. «GEOS». 2020, vol. 2, pp. 270-273. Available at: http://www.ginras.ru/materials/files/MTS-2020-2\%20.pdf (accessed 14.02.2020) (in Russ.).

21. Savko K. A., Samsonov A. V., Kholina N. V., Larionov A. N., Zaitseva M. V., Korish E. H., Bazikov N. S., Terentiev R. A. $2.6 \mathrm{Ga}$ high-Si rhyolites and granites in the Kursk Domain, Eastern Sarmatia: Petrology and application for the Archaean palaeocontinental correlations. Precambrian Research, 2019, vol. 322, pp. 170-192. DOI: 10.1016/j.precamres.2019.01.006 